\title{
It's All Over: Romantic Relationships, Endurance and Loyalty in the Songs of Northern Irish Politically- Motivated Prisoners
}

\author{
Claire Alexandra Green \\ Queen Mary University London, United Kingdom
}

Copyright (c) 2019 by Claire Alexandra Green. This text may be archived and redistributed both in electronic form and in hard copy, provided that the author and journal are properly cited and no fee is charged for access.

\begin{abstract}
This article examines the issue of romantic relationships in the cultural production of politically-motivated prisoners during the recent Northern Irish conflict, with reference to two songs on the subject written by such prisoners: Sad Song for Susan, by republican Bobby Sands, and It's All Over, by an anonymous UDA detainee. I argue that, while most songs produced in this environment dealt with overtly political themes, the few that addressed romantic relationships also inculcated political and cultural norms, both for the prisoners and their partners. Moreover, these pieces shed light on broader ideological aspects of the respective paramilitary movement, the significance of prisoners within it and the mobilisation of broader community support around them, all of which heavily influenced cultural production. The article will contextualise how music was used to cope with and resist the demands of paramilitary imprisonment in Northern Ireland, as well as reinforce the imperatives of endurance and loyalty. I will then demonstrate that these norms were expressed in songs regarding romantic relationships, contributing to a cultural pressure upon prisoners' partners to mirror these values in the domestic sphere.
\end{abstract}

Key Words. Republican, Loyalist, Prison, Songs, Gender, Emotions.

Resumen. Este artículo examina las relaciones sentimentales en la producción cultural de los presos políticos durante el reciente conflicto en Irlanda del Norte, en referencia a dos canciones escritas por estos presos: Sad Song for Susan, escrita por el republicano Bobby Sands, y It's All Over, escrita por un detenido anónimo del UDA. Este artículo argumenta que, mientras que la mayoría de las canciones producidas en este entorno trataban temas abiertamente políticos, las pocas que abordaban relaciones sentimentales también incluían criterios políticos y culturales tanto para los presos como para sus parejas. Es más, estos textos arrojan luz sobre aspectos ideológicos de amplio espectro en cada movimiento paramilitar, la importancia de los prisioneros en este ámbito y la movilización de apoyo 
comunitario a su alrededor, todo lo cual influyó decisivamente en el contenido de estos productos culturales. El artículo contextualiza cómo la música se usaba para lidiar con las exigencias de la prisión paramilitar en Irlanda del Norte, así como para fortalecer los imperativos de resistencia y lealtad. Se demostrará que estas normas fueron expresadas en canciones sobre relaciones sentimentales, contribuyendo a crear una presión cultural sobre las parejas de los presos para reflejar estos valores en el ámbito doméstico.

Palabras clave. Republicano, lealista, prisión, canciones, género, emociones.

Songs written by paramilitary prisoners during the Northern Irish conflict mostly focused on overtly political subject matter. Those that diverged, such as the few concerned with romantic relationships, nonetheless responded to and transmitted political and cultural norms both inside and outside prison, by virtue of the standing of prisoners in wider paramilitary culture. However, while there were shared experiences between prisoners across paramilitary lines, the significance of prisoners in loyalism and republicanism respectively was vastly different. Republicans had a clear enemy in the British state and its security forces, a relationship reflected in prison dynamics. Contemporary events such as internment and reports of brutality at detention centres slotted into a well-established history of Irish nationalist political imprisonment by Britain and its long rhetorical shadow (see McConville). Rather than being seen as simply an obstruction or unfortunate consequence of conflict, imprisonment was a battleground in itself for republicans, and politically-motivated prisoners were thus active participants in both the immediate campaign and broader historical struggle, rather than removed or excluded from it. This long-standing ideological focus on imprisonment had both emotional and practical implications for the mobilisation of the broader community around paramilitary prisoners. When political imprisonment exploded in the early 1970s, there was a blueprint to follow for the glorification of the prisoner, aided by various ballads still in communal use, and for a pragmatic response, including through a tradition of prisoner welfare organisations.

For loyalists, this dynamic was more complex: they felt themselves to be defenders against the encroaching republican threat, a duty in which the state had failed, betraying its unionist and loyalist subjects and jeopardising the existence of Protestant Ulster. To be imprisoned for taking up this duty was the addition of insult to injury, epitomised in the refrain that prisoners" "only crime was loyalty," a feature of songs including the The Men Behind the Wire (Loyalist Song Book, Vol 1). Moreover, most prison staff and police were from Ulster Protestant backgrounds and thus shared ideological similarities, ethno-religious identification, emblems, other cultural artefacts and possibly geographical roots with loyalists, making the binary opposition that lends itself so well to emotive music and cultural mobilisation more difficult. Despite a history of rebellion, loyalists had never experienced imprisonment in the same numbers nor coherent fashion as republicans. They therefore entered the recent conflict at a comparative disadvantage in terms of the weight of this issue within their movement and its cultural production.

Politically-motivated prisoners on both sides of the conflict used music as a means of expression, resistance and bonding, through sing-songs, performances, the production of song books and lyrics, and even recordings. Memoirs by former prisoners highlight the singing of political songs, often at times of high tension, such as following altercations with staff or at significant points in the prison protests. Some prisoners also composed their own lyrics, either initially intended as songs or written as prose and later set to music. These practices provided 
a means of releasing pressure, consolidating bonds and reinforcing commitment to the political goal expressed in the lyrics. Music was also a form of entertainment: when resources permitted, prisoners played popular music on records and instruments, and staged elaborate "concerts," often around birthdays and Christmas. During the republican prison protests, when such equipment was unavailable, both popular and political music were used as means of passing the time and entertaining each other, as well as for antagonistic or more emotionally-charged purposes. The cultural production of female politically-motivated prisoners is far less documented than that of their male counterparts, although it seems that republican women used music in similar ways (Brady et al).

Republican memoirs and secondary sources suggest that music was a key part of prison life. There is comparatively little evidence on the loyalist side. However, there is a far greater abundance of source material related to republicanism and imprisonment in general, both a cause and effect of imprisonment's centrality to that movement. Loyalist prisonerrelated material suggests popular music appears to have been more prevalent than a political canon, with the exception of the recreation of parading culture with flutes, drums and in particular the use of the song The Sash my Father Wore (see The Enemy Within). This suggests an attempt to bring outside loyalist or wider unionist culture into the prison and perhaps to forget or minimise the importance of one's incarceration through cultural production. This is in contrast to the republican tendency to enmesh the prison experience with the broader movement, symptomatic of the ideological differences described above.

Music also linked prisoners with their wider communities. Lyrics and recordings were smuggled out and distributed in the community and, when regulations permitted, records and instruments were brought in. Music also reflected and transmitted values not only amongst prisoners but through prison walls. The performance of well-established pieces reminded prisoners of their history and traditions (invented or otherwise), their aims, and the sacrifices of their forebears. Prisoners' own compositions allowed navigation of these political factors through the prism of their own experience of the contemporary conflict and paramilitary imprisonment. Songs related to paramilitary prisoners and their movements entrenched values with implications spanning both political and personal behaviours among prisoners and the communities that supported and produced them.

However, while these phenomena took place amongst both loyalist and republican prisoners and their wider communities, their effect was tempered by the ideological emphasis placed on the prisoner by the respective movements. Broadly speaking, loyalist prison-based compositions focused on historical events such as the Battle of the Somme, contemporary street battles with republicans, and more general themes such as loyalty that all loyalist paramilitary members were expected to espouse. In comparison, there was a much more robust body of music and song produced in the republican community about prisoners, and within the prison focusing on that specific context. The most widely circulated composition by a loyalist prisoner seems to have been Ulster Girl, written in 1973, the lyrics of which are not prison-related (Rolston 29-30). This is reflective of the aforementioned asymmetry in the ideological significance of imprisonment for the respective movements.

Moreover, while key events and figures are central to republican cultural production, much republican music has a far wider distribution than its loyalist counterparts, partially due to a more organised diaspora, perceived links with other counter-cultural movements, and an uptake by more mainstream artists. This greater reach has a self-perpetuating effect on the themes of the two bodies of music. "Loyalist songs are products of a marginalised and selfreferential world," Wilson writes, meaning that they focus specifically on local, paramilitary and often violent or sectarian themes and imagery (196). Republican music, in contrast, tends to emphasise the broader, more widely relatable themes associated with a particular figure or event, such as loss, isolation, rebellion or bravery. This difference in content both reflects and 
strengthens the comparative cultural marginalisation of loyalism in comparison to republicanism, and is reflected in the songs examined below.

Both the songs examined here travelled outside prison walls. However, there are significant differences in their dissemination. The lyrics to Sad Song for Susan have been published in collections of Sands' work and recorded by republican artists. The song also appears on Music from the Blocks, the album secretly recorded in the H-Blocks by republican prisoners in 1991. While Sad Song for Susan has not been disseminated as widely as Sands' McIlhatton and Back Home in Derry, in part because they were recorded by folk artist Christy Moore, Sands' prominence in the republican pantheon means these lyrics have a farther reach than writing by any other prisoner from this period. In contrast, It's All Over was written by an anonymous UDA detainee and published in the UDA Detainee Song Book, the cover of which states it was "compiled, written and published in Cage 14, Long Kesh, 1974," and sold for $25 \mathrm{p}$. Both songs have been chosen for analysis due to their unusual content in the wider paramilitary canon. However, the broader reach of republican music combined with the posthumous platform that Sands' work attained means that his song has far more circulation, whereas it is unclear if It's All Over had any audience outwith those who obtained a copy of the UDA Detainee Song Book. While the piece indicates it is to be sung to the tune of Honky Tonk Agnes, it is also unclear whether the song would have been sung in practice, rather than its lyrics read. The slow ballad Sad Song for Susan, in contrast, is available as a recording, and has become associated with former IRA prisoner Brendan "Bik" McFarlane, now a regular on the Belfast rebel music scene.

Nevertheless, at the time of composition, Sands could not have conceived of the status he would attain, and both pieces appear to have been written from a deeply personal perspective. Amongst those already inclined to sympathy and support, the association of these songs with Sands or the UDA, and their inclusion in sanctioned publications or recordings, are clear signals of the legitimacy of the themes expressed. The differences in provenance also reflect differences in tone. Sands' song is not overtly political nor prison-related, and appears to have been disseminated because it struck a chord with fellow prisoners. It's All Over, distributed as part of a publication produced by the UDA, is far more explicit in its paramilitary connections as well as its condoning of domestic violence, a theme which I have not found in republican music. Similarly, these differences surely limited the songs' respective circulation: Sands' subject matter could resonate far further afield due to its relative neutrality, in a way that such UDA-specific and more violent themes could not.

Despite these differences in circulation, both songs create a rare window into the emotional life of the prisoner, a possible threat to this figure's military standing. Conversely, the distribution of songs such as these underlined the extent of the prisoners' resolution and sacrifice, reinforcing communal support of the prisoners through exalting these characteristics and encouraging that supporters display the same. Prisoners' compositions concerned with romantic relationships therefore blurred these intertwined personal and political imperatives and had particular implications for the behaviours expected from those engaged in such relationships with prisoners. Perhaps counterintuitively, emotional expression which might have been liberating for prisoners can thus be seen as contributing to restrictive socio-cultural frameworks for those outside.

These processes can be understood as emotional regimes and refuges (Reddy). Politically-motivated prisoner culture, informed by and feeding into that of their wider paramilitary movements, can be seen as an emotional regime, that is, a "set of normative emotions and the official rituals, practices, and emotives that express and inculcate them; a necessary underpinning of any stable political regime" (Reddy 129). These systems provide both direction on which emotions ought to be felt, and a framework through which to feel and express them. This is a comfort and aid to participants in the regime, although, as Reddy 
states, "strict regimes offer strong emotional management tools at the expense of allowing greater scope for self-exploration and navigation" (126). Nevertheless, gaps in such systems often appear, perhaps especially surrounding highly stressful contexts such as imprisonment, and regarding more intimate relationships, for which political practices and norms cannot sufficiently account. This necessitates an emotional refuge, defined as "a relationship, ritual, or organization (whether informal or formal) that provides safe release from prevailing emotional norms and allows relaxation of emotional effort, with or without an ideological justification, which may shore up or threaten the existing emotional regime" (Reddy 129). Compositions related to romantic relationships provided this refuge, but, in promoting behavioural values with clear political foundations, in fact reinforced both the depth and reach of the prevailing emotional regime.

Most analysis of Northern Irish politically-motivated prisoners' use of song focuses on that of republicans, in particular the prolific output of Sands, and emphasises the resistance function of these textual and oral practices (Whalen, Writing and Resistance; Back Home in Derry; Lloyd; McCann). However, as Rolston highlights, loyalist prisoners also produced lyrics that travelled outside prison walls (Loyalism 29). There are differences in the values that paramilitary prisoners were expected to embody according to affiliation or "side." Republicans placed a far greater emphasis on endurance (Rolston and McKeown), and loyalists on loyalty: this is reflected in both the songs examined below and the respective wider paramilitary cultures. However, these two qualities are not dissimilar in their behavioural and emotional implications, a relation perhaps best seen in what they are not: both concepts stand in contrast to weakness and vulnerability (physical or psychological), giving up or breaking down. Both suggest defiance, longevity and standing strong, committed and together in the face of substantial threats or danger.

\section{The Pains of Paramilitary Imprisonment}

The prison was one of the key battlegrounds of the so-called "Troubles": a microcosm of the wider conflict that on occasion drove events on the outside. Gormally et al have divided penal policy during this period into three phases: "reactive containment" (1969-76), "criminalization" (1976-81), and "normalization" (1981 onward), (52). One of the most significant penal policies in the early period of the conflict was the creation of Special Category Status for prisoners sentenced for paramilitary offences, introduced in July 1972 and affording such prisoners certain additional rights and privileges, including freedom of association and the right to wear their own clothes. The majority of politically-motivated prisoners were housed in Long Kesh, segregated by paramilitary affiliation and able to selforganise to a significant degree. Female politically-motivated prisoners, who accounted for around one in twenty prisoners during the conflict and of whom the vast majority were republican, were held at HMP Armagh and later Maghaberry (Corcoran xvii).

In 1976, the phasing out of Special Category Status was the catalyst for five years of republican prison protest, calling for the reinstatement of similar rights. All newly sentenced prisoners would be treated as ordinary criminals and housed in the H-Blocks of the Maze, as Long Kesh had been renamed. This was met by a refusal to wear the prison uniform, sparking the blanket protest, dirty protest, and, finally, two hunger strikes. In May 1981, Sands was the first to die in this phase of hunger striking, followed by nine others. The greater freedoms for which republicans were protesting were mostly granted following the end of the strike, and from November 1982, most republicans conformed with the prison regime. Loyalist prisoners, although fewer in number than republicans, were subject to the same shifts in penal policy and also strongly objected to criminalisation. These prisoners also mounted protests, on issues 
including prison work and segregation by paramilitary grouping, but none were as coherent nor long-running as the republican protests of 1976-1981.

Sykes identifies the pains of imprisonment as the loss of liberty, goods and services, heterosexual relationships, autonomy and security $(64 ; 75 ; 78)$. Although his study of prisoners focused on ordinary inmates, politically-motivated prisoners are clearly not exempt from these deprivations. These demands required coping mechanisms in order to be withstood: "modes of adaptation" (Sykes 79) or "removal activities" (Goffman 58) that could lessen the psychological impact of incarceration. These were impacted but not erased by the nature of paramilitary rather than ordinary imprisonment. Education on political theory and the Irish language, crafts, literary pursuits, the painting of murals and drilling or parading often had a dual resistance-adaptation role: prisoners' political convictions and background were expressed, sharpened and reinforced through these practices, as well as helping them to pass the time and get by (see Mac Ionnrachtaigh; MacAtackney; Whalen, Writing and Resistance; Rolston, Murals; Rolston and Tomlinson).

Coping mechanisms such as these, as well as the use of music, provided simultaneous emotional release alongside demonstrations of political commitment and strength, and were thus of particular value in the paramilitary prisoner context. Any prison entails an imperative upon the prisoner to show strength, or at least conceal weakness, as shown by Sykes, Goffman, Abbott and Cohen and Taylor. This imperative was only strengthened by the addition of paramilitary culture. As Rolston and McKeown demonstrate with regards to male republican prisoners, the demands of "hegemonic masculinity" in this context differed from that of ordinary imprisonment, centring on endurance of violence, deprivation and suffering rather than the ability to inflict it, and fraternal bonds between prisoners were facilitated through their shared political solidarity (265). Nonetheless, "emotions were a potential gateway to vulnerability, not simply personal and social in terms of faltering solidarity but also organizational, threatening to the strategy of resistance within the prison" (Rolston and McKeown 278). Thus emotions had to be carefully managed.

Endurance is a central theme in republican culture, particularly in the context of prisoners: the maxim espoused by Terence MacSwiney, who died on hunger strike in 1920, that "it is not those who can inflict the most, but those that can suffer the most who will conquer" runs through both the actions and imagery of the prison protesters of the 1970s and 1980s (Rolston and McKeown 271). Like Rolston and McKeown, O'Hearn argues that republican prisoners achieved greater solidarity and strength through the endurance of violence and degrading conditions, solidarity that was displayed in "prisoner activities in appropriated spaces that reinforced the culture of resistance: promoting the Irish language, cultural production, and the production of propaganda" (Repression 491). "Charismatic leaders" that developed in the republican prison context were able to tread this fine line between displaying excessive, destabilising vulnerability and the need for emotional expression via cultural production: "Sands contributed to the atmosphere of trust by laying himself bare to the others," but also through his political nous and strategising (O'Hearn, Repression 519). Emotional expression through stories and songs such as those composed or performed by Sands was at its least threatening the more closely it was linked to political resistance. Cultural production that demonstrated and aided emotional endurance was an emotional refuge, providing a release for potentially destabilising emotions through a context that did not threaten, and could even enhance, political respect and commitment.

However, there were limits to prisoners' ability or desire to endure. Adams describes the prevalence and inevitability of the "big D," referring to depression, amongst prisoners, resulting from the fact that "on the outside marriages break up, parents die, children get sick; all normal worries intruding into our impotent abnormality" (18). Imprisonment characterised as "impotent abnormality" tempers the notion that prisoners drew strength from their 
continued contribution and centrality to the conflict. Moreover, the difficulties faced were not always as simple as the prisoners versus the authorities, or the prisoners versus the pains of imprisonment, even for republicans. Various disputes and power struggles took place between different elements of the republican prison leadership (Moloney), and between the prisoners and the outside paramilitary movement, particularly regarding the 1981 hunger strike (O'Rawe). There were also instances of "open rebellion" against directions that prisoners knew would cause them to suffer violence from staff and orderlies during the protests (McKeown 61). The impression of an unshakeable collective, stoic in its endurance and united around a charismatic leader is therefore not fully representative of the realities of the prison context. Nevertheless, this insecurity and tension between the prisoners and with regards to their wider movement may have strengthened the focus on displaying and performing unity and endurance through cultural production: a process of telling each other and themselves what they should feel, and obfuscating what they really did.

Loyalist imagery is closer to the "hegemonic masculinity" referenced by Rolston and McKeown: it is difficult to imagine loyalist icons portrayed as the emblematic bedraggled, physically weak republican prisoner of the H-Block protests. However, nor are the guns, muscles and military drilling of various murals, album covers and other loyalist paraphernalia the full story: the centrality of betrayal and abandonment to loyalist ideology also entails a weakness and vulnerability that must be accounted for and incorporated into cultural production. This vulnerability is configured as the threat of republican violence to local communities, and of the incorporation of Northern Ireland into a united Ireland in which the Ulster Protestant identity is either dissolved or actively oppressed.

In terms of general imprisonment, separation from romantic and familial relationships and the threat of their breakdown during incarceration is one of the greatest sources of insecurity. It is also one of the pains of imprisonment that is most difficult for paramilitary ideology to alleviate. The strong communal element to paramilitary life heavily impacted outside relationships: families and the wider communities were encouraged to mobilise around the prisoners, and paramilitary groups provided funds and other resources to families. Musical events and artefacts generated these funds, and songs also transmitted and reinforced emotional bonds. However, this could not change the fact that prisoners were deprived of romantic relationships but for brief visits severely lacking in privacy. Loyalist prisoners were already hyper-vigilant, if not paranoid, about betrayal and comparatively lacking in both the tradition of communal mobilisation and the strong prisoner-specific self-image that republican cultural production attempted to generate, meaning this insecurity may have been felt even more acutely. The following songs demonstrate how the respective virtues of loyalty and endurance impacted prisoners, their relationships and their cultural production.

\section{Sad Song for Susan and It's All Over}

Sad Song for Susan is written from a post-loss perspective, in which the narrator waits for his former lover to return and is ultimately forced to accept that she will not. This resignation and bearing of acute emotional pain is indicative of the endurance-as-suffering prized in the republican prisoner, although prison is not directly referenced. In fact, much of the song's imagery locates its subject matter in the outside world, such as the first line: "I'm sitting at the window, I'm looking down the street" (Sands 128). The loss of the central figure, along with resignation to it, is the key theme, emphasised by the repetition of the line, "You're gone, you're gone, but you'll live on in my memory" (Sands 129). While the majority of the song implies reflection on a break-up, the fifth and final verse suggests the narrator's loss has been even greater: "Are you happy? Are you all right? I suppose God only knows/ And darling all the people are going to bed and the kids are crying for you/ How can I tell them that you're 
dead?" (Sands 129). It is thus revealed that the narrator is enduring even more profound emotional pain than initially apparent. Moreover, in contrast to the deeply personal, even solipsistic experience of a breakup, this verse introduces a collective element: the narrator has not only his own suffering to bear, but also that of "all the people" and "the kids," for whom he now appears to be responsible. This entails an even greater imperative to remain strong and stoic and carry the familial or communal burden of this loss.

Although "replete with [Sands'] own feelings of emotional loss" (Beresford 84), it is not overtly specific to the prisoner experience. It could thus be understood as no more representative of the impact of imprisonment upon romantic relationships than the tragedy that can befall any partnership. However, Sad Song for Susan also suggests mourning for a wider loss: that of liberty, and the ability to experience loss as a free man. As well as windows and streets, Sands' imagery includes 'the spring when we walked through green fields and skies of gold" (129). These would be painful memories for anyone mourning a relationship or loved one, but even the most devastated free individual can continue to experience streets, fields and skies alone, and hope to meet someone new with whom to share them. Sands, who had already been imprisoned and released once, was sentenced to fourteen years in September 1977, at the age of twenty-three. ${ }^{1}$ While romantic loss is the most prominent theme of Sad Song for Susan, this wider loss of freedom and opportunity by a young man is palpable, revealing a clear prisoner-perspective guiding the wider narrative. The fact that by the time most people outside the the Maze heard the song they knew that his life ended in the prison in May 1981, makes this emotional impact even more acute. Moreover, the discussion of death and explaining it to children is highly emotive in the context of Sands' demise, the communal outpouring of grief that followed it and the knowledge that he left behind a son and other family members.

It seems that Sad Song for Susan was known by Sands' fellow prisoners but not a regular part of his repertoire. O'Hearn states that "Bobby did not sing it very often, just the odd time when the mood was quiet and slow" (Unfinished Song 197), suggesting this piece was more taxing or difficult than others. This is likely because it acknowledges the prisoner's isolation from the outside world but, unlike political pieces, does not offer a distraction from this deprivation. Former republican prisoner Richard O'Rawe writes that Sands composed the song "one rainy afternoon on remand in $\mathrm{H} 1$ when I had the fine company of a guitar to pluck out this tune," and set it to paper at O'Rawe's insistence "on the first morning of the hunger strike" (124). O'Rawe also notes that Sands' wife, from whom he was separated, was named Geraldine, and that when pressed on the identity of Susan "he just smiled and looked ahead as if delving into a lost world of distant - and happier - memories" (125). O'Hearn posits that "close friends felt it was inspired by the breakup with Geraldine" (Unfinishing Song 154). This enigmatic subject contributes to the song's potency, as fellow prisoners could transpose the identity of their own partners or lost loves on to the blank slate of "Susan" more easily than the real-life Geraldine. Simultaneously, the knowledge that their friend and comrade was experiencing these emotions added to the distress of hearing them expressed in song.

The fact that Sad Song for Susan appears to represent the break-down of Sands' marriage has also contributed to its wider reception outside prison. Christy Moore states that it proved too difficult to record: 'I learned it and I tried to sing it but I couldn't fuckin' sing it because it was so... emotional... Oh, there's lots of sad songs, you can get through them but this one was too much for me to sing" (O'Hearn, Unfinished Song 155). This interpretation is not necessarily at odds with the "happy memories" observed by O'Rawe, but reflects the bittersweet nature of prisoners recalling or imagining life outside prison, simultaneously a potential source of emotional strength and devastation.

Cohen and Taylor write of ordinary prisoners that "either one attempts to keep everything going, to continue to live vicariously with wife and children and friends, or one 
abandons oneself to the prison community. The middle state in which relationships are only tenuously maintained seems least bearable" (72). Some politically-motivated prisoners did abandon themselves to the penal community, an option facilitated by the fraternity paramilitary imprisonment entailed. However, paramilitary imprisonment also complicated matters through its strong familial strand, particularly for republicans. Multiple members of the same family may have been incarcerated, political commitment could span generations, various bodies undertook fundraising for prisoners' families, and wives often protested for prisoners' rights. This blurred the distinction between "living vicariously with" wife and family, or jumping headlong into the prison community. Thus many prisoners found themselves in the least bearable "middle state," highly involved in their prison community but unable to fully withdraw into it, and instead tenuously, painfully maintaining echoes of the outside world in their prison life, as expressed in Sad Song for Susan.

While Sad Song for Susan does not explicitly reference the issue of prisoners' partners, it does contribute to a discourse surrounding the role of women in relation to male prisoners. The dissemination of the song, particularly in the context of Sands' death, raises issues of the personal suffering and loss he and other republican prisoners experienced, distinct from the more commonly explored issues of physical suffering. As Moore states, this is an affecting piece, and all the more so the stronger the listener's identification with or support for Sands. Many republicans would not like to consider further emotional turmoil placed upon Sands in addition to the already extreme sacrifice he made as prisoner and then as hunger striker. The more a prisoner's partner was moved by Sands as a political figure, therefore, the clearer the implicit direction to not add to his struggles by voluntarily causing the kind of pain expressed in Sad Song for Susan. Simultaneously, there is an even deeper respect and appreciation generated for Sands through his ability to endure significant emotional, personal strain and sacrifice as well as displaying these virtues in his political and physical actions, further reinforcing the imperative to protect those he represents from increased suffering. Prisoners' partners who had to endure and take on the wider, familial burden of grief expressed in Sands' fifth verse may also find their identification with him strengthened through the suggestion that he empathised with their own difficulties, narrowing the conceptual gap between the prisoner's experience and the impact of his imprisonment upon his family.

While Sad Song for Susan is more resigned, It's All Over displays anger and resentment in response to a relationship breakdown. It is far more explicit about both the overlap between personal and political commitments demanded of prisoners' wives, and the potential consequences of not meeting them. Unlike the ambiguous loss in Sad Song for Susan, the conflict in It's All Over is explicitly described and unequivocally prison-related. "You promised me when I was in prison/ That you would always love me and be true," the first lines report, "But now I'm being told by other people/ About the things that you've begun to do" (U.D.A. Detainee). The issue of infidelity is made even clearer in the final verse: "I didn't think that my wife would be/ Unfaithful, I always thought that she/ Would play the game, but when they/ Let me out of Long Kesh Prison/ I'll make her wish she'd never heard my name".

This reference to "playing the game" is revealing of the pressures placed on prisoners' wives to accept their husbands' often lengthy absences. This pressure was in part a result of the tight-knit communities from which many prisoners came. The wife of a republican prisoner who worked in a local bar stated that "all his friends either drank or worked in the bar ...so if I'd put a foot wrong he'd have been told right away. It used to get on my nerves that, their eyes were always on you" (Gaucher 202). The implication of this surveillance is not only that the marriage would fall apart but also potentially more violent, as the final line of It's All Over makes clear. 
In one sense, this aspect of paramilitary culture was intertwined with general expectations of women: the sentiment expressed by the aforementioned republican prisoner's wife that "they make excuses for a man flying his kite, but if a woman does it, she's a tramp and no good" (207) would resonate in a far wider breadth of contexts and cultures than the paramilitary strongholds of Northern Ireland. On the other hand, paramilitaries had a notable degree of power over the communities in which they operated. As well as concerns over standards of behaviour more common to a range of social groups, there was also a clear pragmatic interest in maintaining prisoners' home lives, both for prisoners' morale and the practical benefits of keeping their wives committed to the cause. The pivotal role of republican prisoners' families in the ending of the 1981 hunger strike is indicative of the disruptive impact they could have on paramilitary strategy. The particular importance of prisoners in republicanism strengthened the moral imperative of endurance and loyalty, as an interviewee in Rolston and Tomlinson's study of long-term imprisonment in Northern Ireland describes: 'It wouldn't be so bad if your husband wasn't in prison, say, and you were seeing another man. But because your husband's in prison, I mean, that would stay with you forever. That's the kind of stigma that I imagine would be left the children too, especially in these nationalist areas where the prisoners really get the support" (181).

However, the issue of support for prisoner-husbands was not a simple question of paramilitary power, stigma and threats. "Playing the game" implies an accordance between husband and wife regarding each other's behaviour. This was not only underpinned by the danger of violence or reputational damage, but also by a commitment to a shared political ideal. "I want to wait for him because he's my husband and we had a good relationship, and I have two children belonging to him and I'm determined these people, the Brits, are not going to smash that," states one woman in Rolston and Tomlinson's investigation (176). In this regard, supporting their husband was not a burden placed on women by a paramilitary group and underlined by threats or coercion, but an autonomously chosen act of resistance. Moreover, it may have been a fully expected and accepted part of the marriage from the beginning. Maintaining the relationship and family home was thus a political act in itself. It was also not the case that women were so coerced that they could not choose to leave. A republican mother recalls of her newly-detained son's wife that: "...when I said I would arrange for her to get the Green Cross, she said: 'You needn't get me any Green Cross, I won't be going to visit him" ...And she never did. Eventually him and her separated, and she's away now in Australia" $(2010,15){ }^{2}$ Threats from scorned husbands may have been just as representative of rhetorical machismo than actual danger.

This umbilical relation between the domestic and the political is expressed in the second verse of It's All Over, in which the narrator describes how "They put me in Long Kesh because I'm/ Loyal, for fighting I.R.A. with bomb and gun," and asks "I never would betray my friends and comrades/ So why have you betrayed me as/ You've done". This is not simply a cri de cœur from a betrayed partner, but the tale of a loyalist husband betrayed by a loyalist wife. For the composer, betrayed by his country and imprisoned for being "loyal," such domestic treachery reflects the unjust treatment at the hands of the state, and is doubly painful for it. The qualities demanded of prisoners were expected to be displayed by their wives, and also by the community in relation to prisoners' domestic situations. The wife of the narrator in It's All Over is the main object of his scorn, but her partner is also addressed: "The scum who chased another prisoner's/ Woman, Had better stop or else go on the run". This reference to "another prisoner" suggests this may be another paramilitary member, and perhaps a special opprobrium reserved for the breaking of these political bonds distinct from the general pain of infidelity.

Remaining faithful may have been the most emotive demand placed on prisoners' wives, but it was not the only way in which they were required to "play the game." More 
mundane was the wider imperative to maintain the family home, raise children, attend visits and keep the strain of this burden away from the prisoner-husband. This demand fell primarily on the family, but was supported to a degree by prisoner-related organisations. These were stronger in different areas and could only provide limited resources; perceived over-reliance was also an issue of pride, as women were aware they were not the only ones in need. "The organisation would have provided so much but there was so many men from the area inside you couldn't go to them all the time," one loyalist woman told the Time Stands Still project (13). A republican woman supporting her imprisoned brother noted that "when we eventually got the Green Cross money from the local republicans, it was a Godsend" (8). Such support was the beneficial counterpoint to the behavioural standards imposed by the wider community. It also likely enhanced wider familial commitment to the prisoner's cause, or at least mitigated against accusations of abandonment. Both republican and loyalist paramilitaries placed a great emphasis on their communal defence role, of which there was a pastoral as well as physical force manifestation. It could have been problematic if prisoners' families had been left to cope entirely alone, and the sense that families were being somewhat looked after by their organisation also likely boosted prisoners' allegiance to that body. However, republican communities were better prepared in terms of historical precedent and thus more easily organised: the Green Cross has its roots in the 1940s, whereas comparable loyalist welfare institutions did not exist before the 1970s. This may also have strengthened the personal paranoia expressed in It's All Over, in lieu of more comprehensive communal vigilance and structures.

The expectation that women would maintain the domestic sphere reflects the endurance maxim identified by Rolston and McKeown as integral to republican prisoners' emotional management. The loyalty demanded from loyalist prisoners is closely connected, and clearly expected from many of their wives. Women interviewed by Rolston and Tomlinson report keeping details of their domestic lives from their husbands (77), as do those featured in Time Stands Still: "The last thing you wanted to do was give them more anxiety.... They had enough trouble to worry about within the jail system, and to try and stay alive within it" (14). In handling these problems alone, or with the limited help of outside organisations, women were supporting both their husbands and the movement, demonstrating the ability to endure and stay loyal so that paramilitary prisoners could do so. Whalen examines the attempts made by republican prisoners in the post-hunger strike period to address their wives' sacrifices through creative writing, particularly in their magazine An Glór Gafa (Writing and Resistance 141-168). This greater openness and emotional exploration included grappling with the issue of infidelity, and an acknowledgement that, as Whalen states "like the prisoners themselves, partners on the outside often felt a duty - imposed from within and without - to dwell behind an emotionless facade" (Writing and Resistance 166).

Much of this inward analysis was not conducted until the 1990s, and took place amongst a group of particularly culturally and academically-minded republican prisoners, which may not be representative of loyalist paramilitaries nor all republicans. The questions from one loyalist wife of "How many of our husbands during the last twenty-odd years have turned round and said: 'How did you cope? What did you feel?"' (Time Stands Still 15-16) likely still rang true for many, despite those efforts. What is most significant about Whalen's examination of pieces in An Glór Gafa is that it demonstrates the centrality of cultural production to exploring, reinforcing and transmitting norms amongst paramilitary prisoners and their wider community that went far beyond the political and encompassed the domestic realm. Sad Song for Susan and It's All Over did the same, only the norms and their implications differed.

Like the prisoners, their partners outside were faced with various options to get through the period of imprisonment (see Rolston and Tomlinson). They could choose to fully 
abandon themselves to the prisoner cause, engaging in campaigning and other political activity, or abscond from this connection: divorce, emigrate or be unfaithful. Many, however, found themselves in the middle ground, in which the the paramilitary and the domestic intermingled, and motivation to support one's husband incorporated a breadth of push and pull factors, from the intimate bonds of a marriage to a political belief or coercive social stigma. Songs produced on this theme in prison were an important means for prisoners to explore their feelings, particularly in a context in which opportunities for emotional exploration and expression were limited. However, such pieces did not exist in a vacuum and contributed to the burden placed upon wives, girlfriends and other women in the community, gladly undertaken or otherwise, to value endurance and loyalty over more complex personal and emotional needs.

\section{Notes}

1 “Six get 14 years each on arms charges". The Irish News. 8 September 1977, p. 2 col. e.

${ }^{2}$ The Green Cross was a republican prisoners' welfare organisation.

\section{Works Cited}

Adams, Gerry. Cage Eleven. Dingle, Co. Kerry: Brandon, 1990.

Abbott, Jack Henry. In the Belly of the Beast: Letters from Prison. New York: Random House, 1982.

Beresford, David. Ten Men Dead. London: Harper Collins, 1987.

Brady, Evelyn et al. In the Footsteps of Anne: Stories of Republican Women Ex-Prisoners. Belfast: Shanway, 2011.

Cohen, Stanley and Laurie Taylor. Psychological Survival: The Experience of Long-Term Imprisonment. Middlesex: Penguin Books, 1972.

Corcoran, Mary S. Out of Order: The Political Imprisonment of Women in Northern Ireland, 1972-1998. Devon: Willan Publishing, 2006.

Gaucher, Bob, ed. Writing as Resistance: The Journal of Prisoners on Prisons Anthology (1988 - 2002). Toronto: Canadian Scholars' Press Inc., 2002.

Goffman, Erving. Asylums. Harmondsworth, Middlesex: Pelican Books, 1961.

Gormally, Brian, Kieran McEvoy and David Wall. "Criminal Justice in a Divided Society: Northern Ireland Prisons". Crime and Justice 17 (1993): 51-135.

Lloyd, David. Irish Culture and Colonial Modernity 1800-2000: The Transformation of Oral Space. New York: Cambridge University Press, 2011.

Loyalist Song Book, Vol 1.

Mac Ionnrachtaigh, Feargal. Language, Resistance and Revival: Republican Prisoners and the Irish Language in the North of Ireland. London: Pluto Press, 2013.

McAtackney, Laura. An Archaeology of the Troubles: The Dark Heritage of Long Kesh/ Maze Prison. Oxford: Oxford University Press, 2014.

McCann, Fiona. "Embodying Resistance: The Poetry of Bobby Sands". Études irlandaises. 40-1 (2015): 325-327.

McConville, Seán. Irish Political Prisoners, 1920-1962: Pilgrimage of Desolation. London: Routledge, 2014.

McKeown, Laurence. Out of Time: Irish Republican Prisoners, Long Kesh 1972-2000. Belfast: Beyond the Pale, 2001.

Moloney, Ed. Voices from the Grave: Two Men's War in Ireland. London: Faber and Faber, 2010 .

O’Hearn, Denis. Bobby Sands: Nothing But an Unfinished Song. London: Pluto Press, 2006. 
- "Repression and Solidary Cultures of Resistance: Irish Political Prisoners on Protest". American Journal of Sociology 115. 2 (September 2009): 491-526.

O’Rawe, Richard. Blanketmen. Dublin: New Island, 2005.

Reddy, William M. The Navigation of Feeling. Cambridge: Cambridge University Press, 2001.

Rolston, Bill and Mike Tomlinson. "Long-Term Imprisonment in Northern Ireland: Psychological or Political Survival?" The Expansion of European Prison Systems. Eds. Bill Rolston and Mike Tomlinson. Belfast: The European Group for the Study of Deviance and Social Control, 1986. 299-333.

Rolston, Bill. "Music and Politics in Ireland: The Case of Loyalism". Politics and Performance in Contemporary Northern Ireland. Eds. John P. Harrington and Elizabeth J. Mitchell. Amherst, MA: University of Massachusetts Press, 1999. 29-56. "Prison as a Liberated Zone: The Murals of Long Kesh, Northern Ireland". State Crime Journal 2. 2 (Autumn 2013): 149-172.

Rolston, Bill and Laurence McKeown. "Male Republican Prisoners in Northern Ireland: Resistance, Emotions and Homosociality". State Crime Journal 6. 2 (Autumn 2017): 265-285.

Sands, Bobby. Skylark Sing Your Lonely Song. Cork: Mercier Press, 1982

Sykes, Gresham M. The Society of Captives: A Study of a Maximum Security Prison. Princeton, NJ: Princeton University Press, 1958.

The Enemy Within (Inside Long Kesh 1990). BBC.

Time Stands Still: The Forgotten Stories of Prisoners Families. Newtownabbey: Island Publications/Farset Community Think Tanks Project, 2010.

UDA Detainee Song Book, 1974.

Whalen, Lachlan. Contemporary Irish Republican Prison Writing: Writing and Resistance. New York: Palgrave Macmillan, 2007.

. "I Wish I Was Back Home in Derry': Songs Composed in the H Blocks and the Paradox of Exile". Irish Migrants in New Communities: Seeking the Fair Land? Ed. Mícheál Ó hAodha and Máirtín Ó Catháin. Maryland: Lexington Books, 2014. 131143.

Wilson, David A. "Ulster Loyalism and Country Music, 1969-85". Eds. Charles K. Wolfe and James E. Akerson. Country Music Goes to War. Lexington, KY: University Press of Kentucky, 2005. 192-207.

Claire Alexandra Green is a PhD candidate in History and Law at Queen Mary University of London. Her research focuses on the use of music by and in relation to politicallymotivated prisoners in the Northern Irish conflict, particularly its role in identity construction, asserting and contesting authority and mobilising communal support. Her wider research interests include nationalism, political music and counter-cultural movements.

c.a.green@qmul.ac.uk 